\title{
Influences of geothermal sulfur bacteria on a tropical coastal food web
}

\author{
Pascal Pierre-Yves ${ }^{1,{ }^{*}}$, Dubois Stanislas ${ }^{2}$, Goffette Anais ${ }^{1}$, Lepoint Gilles ${ }^{3}$
}

${ }^{1}$ Univ Antilles, UMR Evolut Paris Seine 7138, Equipe Biol Mangrove, BP 592, F-97159 Pointe a Pitre, Guadeloupe, Guadeloupe.

${ }^{2}$ IFREMER, DYNECO LEBCO, Ctr Bretagne, CS 10070, F-29280 Plouzane, France.

${ }^{3}$ Univ Liege, Ctr MARE, Lab Oceanol, 15 Allee 6 Aout, Quartier Agora,Bat B6C, B-4000 Liege, Belgium.

* Corresponding author : Pierre-Yves Pascal, email address : pypascal@univ-ag.fr

\begin{abstract}
:
The activity of the geothermal plant at Bouillante in Guadeloupe (French West Indies) releases thioautotrophic bacteria into the coastal environment. Fish counts reveal that fish abundance increases with higher availability of this bacterial resource. In order to evaluate the trophic role of these bacteria, isotopic compositions ( $\mathrm{C}, \mathrm{N}, \mathrm{S}$ ) of potential consumers were evaluated on transects at increasing distance from the source of bacteria. The 3 mobile fish species examined (Abudefduf saxatilis, Acanthurus bahianus, and Stegastes partitus) ingested and assimilated chemosynthetic bacteria. Similarly, the isotopic composition of the mobile sea urchin Diadema antillarum was different close to the discharge channel, suggesting a diet mainly composed of sulfur bacteria. In contrast, endofauna sampled from the nematode community did not show a diet influence by chemosynthetic bacteria. A broad variety of epifaunal organisms with passive and active suspension-feeding activities were also investigated, including sponges (Aplysina fistularis and lotrochota birotulata), barnacles (Balanus sp.), bivalve molluscs (Spondylus tenuis) and cnidarians (Pseudopterogorgia sp.), but no strong evidence for sulfur bacteria contributions were determined in the diets of any of these organisms. This was also true for the omnivorous predator annelid Hermodice carunculata. In this coastal oligotrophic environment, only certain opportunistic species seem to benefit from the emergence of a new food item such as chemosynthetic bacteria.
\end{abstract}

Keywords : Shallow vent, Food web, Sulfur bacteria, Stable isotope 


\section{Introduction}

Shallow water hydrothermal vents are generally located above subducting slabs, especially along volcanic arcs, and are commonly detected by the presence of streams of gas bubbles (Gamo \& Glasby 2003). They are found in many regions of the world, from tropical to polar environments (Tarasov et al. 2005), and present a general functioning similar to deepsea vents. Heat-driven chemical reactions with rocks generate emissions of hot fluid with abundant sulfur compounds suitable for chemosynthetic bacteria (Van Dover 2000). Shallow vents present a low faunal biomass with few, if any, obligate species (Tarasov et al. 2005). They differ from deep-sea vents which are characterized by a high biomass of associated fauna with low species diversity, principally consisting of species obligate to such sites (Tunnicliffe 1991, Van Dover 2000). This transition between shallow and deep vents coincides approximately with the change from euphotic zone to aphotic zone (Tarasov et al. 2005). In the euphotic environment of shallow vents, food webs appear to be principally based on pelagic and benthic photosynthetic primary production, whereas chemosynthetic components often play a secondary trophic role (Tarasov et al. 2005, Sweetman et al. 2013). According to studies, chemosynthetic bacteria appear as an alternative resource ingested when other food items are not available. However, they can also play a trophic role for species from vents were food resources are not limited (Stein 1984, Trager \& De Niro 1990, Comeault et al. 2010, Zapata-Hernández et al. 2014a). Results from cold seep environments are also variable as important trophic roles for chemosynthetic bacteria are observed from intertidal to subtidal seeps of brine (Powell et al. 1986), petroleum (Spies \& DesMarais 1983, Montagna \& Spies 1985) and methane (Jensen et al. 1992, Judd et al. 2002, Sellanes et al. 2011).

The aim of the present study is to evaluate the trophic role of large sulfur bacteria released by a geothermal plant in the tropical environment of Guadeloupe Island (French West Indies). Geothermal hot water is artificially pumped from deep reservoirs in order to 
produce electricity and then cooled with seawater before being released in the sea. Environmental conditions in the discharge channel support development of sulfur-oxidising bacteria. Water discharges are linked with plant functioning and are regularly stopped for maintenance work. This irregular but predictable flux of geothermal chemosynthetic bacteria gives a unique opportunity to determine its influence on the diet of coastal fauna. In order to evaluate the effects of this bacterial biomass, abundance of their potential consumers was measured along a transect of increasing distance from the mouth of the discharge river. Then, $\mathrm{C}, \mathrm{N}, \mathrm{S}$ isotopic compositions of these potential consumers were analysed to assess the extent of bacterial assimilation.

\section{$\underline{\text { Material and method }}$}

\section{Study area}

The Bouillante geothermal field is located on the west coast of Basse-Terre Island, the western island of Guadeloupe belonging to the volcanically active islands of Lesser Antilles (Fig. 1). The town has been named "Bouillante", which means "boiling" in French, as this area is characterized by hydrothermal manifestations such as hot springs, mud pools, steaming grounds and fumaroles. The deep geothermal fluid (total dissolved solids around 20 $\mathrm{g} \mathrm{L}^{-1}, \mathrm{pH}=5.3$ ) is the result of a mixture comprising $58 \%$ seawater and $42 \%$ meteoric water reacting with volcanic rocks (Brombach et al. 2000, Sanjuan et al. 2001). The water flowing through the geothermal aquifer has a homogeneous composition at the spatial scale of the Bouillante region and the reservoir represents a total volume larger than 30 million $\mathrm{m}^{3}$ with a temperature of $250-260^{\circ} \mathrm{C}$ (Mas et al. 2006). In 1986, a geothermal plant without reinjection started producing electricity by exploiting water coming from a $340 \mathrm{~m}$ deep well (Jaud \& Lamethe 1985). Additional deeper wells (1000-1200 m) are now used to reach a power output of 16 MWe (Mas et al. 2006). All the residual water is mixed with pumped seawater in order 
to drop the temperature to $45{ }^{\circ} \mathrm{C}$ before it is all returned to the sea through a discharge channel (Fig. 1). The salinity of released water is approximately 33 and the $\mathrm{pH}$ is 7.3 . Compared to normal seawater, the water released by the plant is enriched in trace metal ions (Sanjuan et al. 2001, Lachassagne et al. 2009) and characterized by a high concentration of dissolved $\mathrm{H}_{2} \mathrm{~S}$ reaching $35-45 \mathrm{mg} \mathrm{L}^{-1}$ in the steam condensate (Mas et al. 2006). In the discharge channel, environmental conditions are favourable for the development of benthic sulfur-oxidizing bacteria of the genus Thiomicrospora sp., covering the surface of the benthic cyanobacteria Pectonema sp. (O. Gros pers. obs.) (Fig. 2). Because of the strong channel outflow $\left(2.5 \mathrm{~m}^{3} \mathrm{~s}^{-1}\right)$, these white bacteria are continuously ripped off and spread into the bay. Under regular weather conditions, coastal currents in the bay are oriented to the north (ANTEA 2005). Previous experiments releasing dye into the channel revealed a progressive dilution of water from the outlet to a distance of approximately $300 \mathrm{~m}$ (PARETOIMPACTMER 2009). This channel is the only source of sulfur bacteria in the surficial environment of the bay.

\section{Sampling}

Sulfur bacteria were sampled in the discharge channel during four consecutive periods throughout the month of January, 2014. Spatial and temporal approaches were simultaneously used to determine the influence of released bacteria. Potential consumers were sampled at five different sampling stations along a transect: at the discharge channel outlet (hereafter called 0 m station) and 80, 160, 280 and $400 \mathrm{~m}$ away from the outlet (Fig. 1). Moreover sampling was performed both during the regular functioning of the geothermal plant $\left(4^{\text {th }}\right.$ and $6^{\text {th }}$ February, 2014) and after two weeks of pause due to maintenance works (26 ${ }^{\text {th }}$ and $27^{\text {th }}$ March, 2014). Each sampling session was conducted within less than three days. After 24 hours of inactivity of the geothermal plant, sulfur bacteria completely disappeared from the channel. 


\section{Abundance}

Diver-operated video was used to evaluate fish abundances. At each station, two open width line transects of $20 \mathrm{~m}$ long were demarked by ropes at the surface of the rocky substrate $(\approx 3 \mathrm{~m}$ depth). The same operator filmed all videos with a small action camera (GoPro) while swimming at regular speed $\left(0.8 \mathrm{~m} \mathrm{~s}^{-1}\right)$ along the transect lines $(5 \mathrm{~cm}$ above the bottom) and keeping the camera steady and perpendicular to the bottom. Each transect was repeated five times with at least four minutes between each shooting. A single viewer analysed all videos. Fish were counted and identified to species or genus levels, and abundances were estimated using freeze-frame when the number of specimens in movement was too great to count accurately otherwise. Due to the frequent large schools of Haemulon spp. repeatedly crossing transects and inducing large variability in fish counts, this species was consequently removed from the analysis of the total fish community.

\section{Isotopic composition}

Potential consumers of bacteria were randomly collected within a $20 \mathrm{~m}^{2}$ area around each sampling station ( $n=3$ for each species of consumers sampled at each station). One centimetre of surficial sediment was collected from each station and each nematode sample $(n=3)$ was composed of 700 specimens haphazardly removed from each sample after extraction using Ludox HS40 (de Jonge \& Bouwman 1977). According to their availability, three types of potential bacteria consumers were collected at each sampling station: grazers (echinoderm: Diadema antillarum), suspension-feeders (sponges: Iotrochota birotulata, Aplysina fistularis; crustacea: Balanus sp.; mollusc: Spondylus tenuis; cnidaria: Pseudopterogorgia sp.) and predators (annelid: Hermodice carunculata). Fishes with a grazing behaviour were collected in stations 0 and $400 \mathrm{~m}$ and three adult specimens of Abudefduf saxatilis, Acanthurus bahianus and Stegastes partitus were speared. Sub-samples of coarse sponges and gorgonian were acid-treated $(1 \mathrm{M} \mathrm{HCl})$ for $\delta^{13} \mathrm{C}$ measurement whereas, 
untreated sub-samples were used for $\delta^{15} \mathrm{~N}$. Calcium carbonate $\left(\mathrm{CaCO}_{3}\right)$ is the principal source of inorganic carbon in coral reefs (Gattuso et al. 1999) and is significantly more enriched in ${ }^{13} \mathrm{C}$ than organic carbon (Kennedy et al. 2005). When manual extraction is not possible, acidification is thus required to remove those calcareous components whose isotopic composition is not related to animal diet (Kolasinki et al. 2008). A dissecting microscope was used to isolate muscles of crustacean, mollusc, echinoderm, annelid and fish as well as the stomach contents of fishes. Samples were frozen, freeze-dried and ground into a homogeneous powder by using a ball mill. C, N, S elemental and isotopic compositions were then measured with an isotope ratio mass spectrometer (IsoPrime100, Isoprime, UK) coupled in continuous flow to an elemental analyser (vario MICRO cube, Elementar, Germany). Isotope ratios were conventionally expressed as $\delta$ values in \%o (Coplen 2011) relative to $\mathrm{C}, \mathrm{N}$ and S international standards, i.e. Vienna PeeDee Belemnite (VPDB) for carbon, atmospheric air for nitrogen and Canyon Diablo triolite (VCDT) for sulphur. International Atomic Energy Agency (IAEA, Vienna, Austria) certified reference materials calibrated against the international isotopic references IAEA-C6 $\left(\delta^{13} \mathrm{C}=-10.8 \pm 0.5 \%\right)$, IAEA-N2, $\left(\delta^{15} \mathrm{~N}=20.3 \pm\right.$ $0.2 \%)$ and IAEA-S1 $\left(\delta^{34} \mathrm{~S}=-0.3 \%\right)$ were used as primary analytical standards, and sulphanilic acid $\left(\delta^{13} \mathrm{C}=-25.9 \pm 0.3 ; \delta^{15} \mathrm{~N}=-0.12 \pm 0.4 ; \delta^{34} \mathrm{~S}=5.9 \pm 0.6\right)$ as a secondary analytical standard. Isotopic ratios of samples were normalized using primary analytical standards. Standard deviations on multi-batch replicate measurements of secondary analytical (sulphanilic acid) and lab standards (fish tissues) analyzed interspersed among the samples (2 lab standards for 15 samples) were $0.1 \%$ for $\delta^{13} \mathrm{C}, 0.3 \%$ for $\delta^{15} \mathrm{~N}$ and $0.5 \%$ for $\delta^{34} \mathrm{~S}$.

\section{Data analyses}

One-way analysis of variance (ANOVA) was used to analyse the differences in fish abundances along the transects and the Tukey test was used for post-hoc comparisons. The relationship between variations in abundance and geothermal plant activity was tested using 
bilateral-independent-samples t-tests. All those data were previously tested for normality by Shapiro-Wilk test. The nonparametric Kruskal-Wallis test was used to test differences in isotopic composition ( $\mathrm{C}, \mathrm{N}$ and $\mathrm{S}$ ) of consumers. All statistical analyses were performed using R. Values are presented as means \pm standard deviations (s.d.) excepted when specified.

Bayesian isotopic mixing models were used to determine contributions of bacteria to diets of D. antillarum, A. bahianus, A. saxatilis and S. partitus. SIAR (Version 4.2) (Parnell et al. 2010) incorporates the variability of consumers and trophic enrichment factors (TEFs) (i.e., the net isotopic composition change in a consumer and its ingested food sources) to produce the percent contribution of each source to a consumer's diet. TEFs are key factors when it comes to evaluate contributions of food sources to animal diets. TEFs used were $1.1 \pm$ $0.5 \%$ for $\delta^{13} \mathrm{C}, 2.2 \pm 0.5$ for $\delta^{15} \mathrm{~N}$ and $2.0 \pm 0.7 \%$ for $\delta^{34} \mathrm{~S}$ (McCutchan et al. 2003). These TEFs are typically used in isotope study and are appropriate when consumers are not starved (Vander Zanden et al. 2015, Lefebvre \& Dubois 2017). Variations of 20\% in these TEFs do not change the conclusion of the present study as they induce only small variations of $1.5 \pm$ $0.9 \%$ in model results.

A two-step procedure was performed to run the SIAR modelling at station $0 \mathrm{~m}$. First, TEFs (McCutchan et al. 2003) were subtracted from isotopic compositions of consumers caught at station $400 \mathrm{~m}$ in order to determine the isotopic compositions of bulk diets of each consumer in an environment without bacteria; $400 \mathrm{~m}$ from the discharge outlet being beyond the $300 \mathrm{~m}$ extent of dilution in water established in earlier dye-releasing experiments (PARETO-IMPACTMER 2009). Then, average values and standard deviations of those results are used as "food sources" in models using isotopic compositions of consumers from station $0 \mathrm{~m}$ in contact with bacteria. For each consumer, three isotopes ratios $(\mathrm{C}, \mathrm{N}, \mathrm{S})$ and two potential food sources are considered: $i$ ) bacteria and $i$ ) average isotopic composition of consumers' bulk food sources at station $400 \mathrm{~m}$. It should be noted that this evaluation of the 
contribution of bacteria to diets is based on the assumption that bacteria is the only food item in which contribution is changing in fauna diets between 0 and $400 \mathrm{~m}$ stations. A second assumption is that consumers are not moving along transect. As consumers such as fishes are mobile, $400 \mathrm{~m}$ fishes can ingest bacteria. As a result, SIAR model tends to underestimate the contribution of bacteria for mobile consumers.

The model was run with $10^{6}$ iterations and burn-in size was set as $10^{5}$. Model solutions are presented using credibility intervals of probability density function distributions (Parnell et al. 2010).

\section{$\underline{\text { Results }}$}

Abundance

During geothermal plant production activity, the total number of fish at the discharge channel outlet was significantly higher than in other stations (ANOVA; $p<0.001$ ) and significantly higher than when the plant was stopped (bilateral t-test; $\mathrm{p}<0.001$ ) (Fig. 3). Fish abundances at other stations were not affected by the geothermal plant activity (bilateral ttest; non-significant). When bacteria were being released, A. bahianus and A. saxatilis at station $0 \mathrm{~m}$ both presented higher abundances than in other stations (ANOVA; $\mathrm{p}<0.001$ ) and higher abundances than in station $0 \mathrm{~m}$ when the plant was stopped (bilateral t-test; $\mathrm{p}<0.001$ ). Variations were different for Stegastes spp. as abundances were higher in station $0 \mathrm{~m}$ (ANOVA; $\mathrm{p}<0.001$ ) but were not affected by the functioning of the plant (bilateral t-test; non-significant).

\section{Isotopic composition}

Bacteria released by the geothermal plant of Bouillante were regularly collected during the month preceding the sampling of their potential consumers and presented a $\delta^{13} \mathrm{C}$ of $-18.2 \pm 2.9 \%$, a $\delta^{15} \mathrm{~N}$ of $-2.4 \pm 2.3 \%$ and a $\delta^{34} \mathrm{~S}$ of $10.9 \pm 3.1 \%$. Among potential consumers of station $400 \mathrm{~m}$, the lowest $\delta^{15} \mathrm{~N}$ was presented by the two sponge species $A$. 
fistularis $\left(\delta^{15} \mathrm{~N}=2.75 \pm 0.42 \%\right.$ ) and I. birotulata $\left(\delta^{15} \mathrm{~N}=3.80 \pm 0.22 \%\right.$ o $)$ and the cnidaria Pseudopterogorgia $\mathrm{sp}\left(\delta^{15} \mathrm{~N}=3.46 \pm 0.10 \%\right.$ ) (Fig. 4). Potential consumers with highest $\delta^{15} \mathrm{~N}$ were the fish $S$. partitus $\left(\delta^{15} \mathrm{~N}=8.69 \pm 0.21 \%\right.$ ), the urchin D. antillarum $\left(\delta^{15} \mathrm{~N}=5.99 \pm 0.42\right.$ \%o) and the annelid $H$. carunculata $\left(\delta^{15} \mathrm{~N}=5.65 \pm 2.49 \%\right.$ ) and those organisms also present the highest $\delta^{13} \mathrm{C}(-15.24 \pm 2.49,-13.26 \pm 0.42$ and $-13.63 \pm 1.50 \%$ respectively).

Proximity to bacteria release did not affect $\delta^{13} \mathrm{C}$ and $\delta^{15} \mathrm{~N}$ (Kruskall-Wallis tests, $\mathrm{p}>$ 0.05) for 7 of the 11 studied organisms: nematode, suspension-feeders (I. birotulata, A. fistularis, Balanus sp., S. tenuis and Pseudopterogorgia sp.) and predator (H. carunculata) (Fig. 5). However, the urchin D. antillarum presented $\delta^{13} \mathrm{C}, \delta^{15} \mathrm{~N}$ and $\delta^{34} \mathrm{~S}$ significantly affected at station $0 \mathrm{~m}$ (Kruskall-Wallis tests, $\mathrm{p}<0.01, \mathrm{p}<0.01$ and $\mathrm{p}<0.05$ respectively) (Fig. 6). Between stations 0 and $400 \mathrm{~m}$, the fish A. bahianus presented significant differences in $\delta^{13} \mathrm{C}$ and $\delta^{34} \mathrm{~S}$ of muscle (Kruskall-Wallis tests, $\mathrm{p}<0.05$ ) and in $\delta^{13} \mathrm{C}$ of gut content (Kruskall-Wallis tests, $\mathrm{p}<0.05$ ). A. saxatilis and $S$. partitus both presented significant differences in $\delta^{15} \mathrm{~N}$ of muscles (Kruskall-Wallis tests, $\mathrm{p}<0.05$ ) and in $\delta^{15} \mathrm{~N}$ of gut contents (Kruskall-Wallis test, $\mathrm{p}<0.05)$.

After a two week pause in activity at the plant for maintenance work, $\mathrm{C}$ and $\mathrm{N}$ isotopic compositions of all studied species of fish followed the same trend: an enrichment in ${ }^{13} \mathrm{C}$ and in ${ }^{15} \mathrm{~N}$. Statistically, changes in isotopic composition of muscle tissues were only significant for $\delta^{13} \mathrm{C}$ of A. bahianus and A. saxatilis (Table 1).

SIAR was run only for the organisms showing statistically different isotopic composition between station 0 and $400 \mathrm{~m}$. SIAR outputs suggested that among the four studied organisms, all assimilated bacteria but in different proportions. Mean bacterial contributions (with lower and higher $95 \%$ credibility interval) to the diets of D. antillarum, A. bahianus, A. saxatilis and S. partitus were respectively 66\% (44-92), 47\% (7-86), 27\% (6-50) and $37 \%$ (15-58) (Fig. 7). 


\section{$\underline{\text { Discussion }}$}

The most striking results of our study are that fishes seem to assimilate significant amount of bacteria at geothermal outlets and show dramatically increased abundance when sulfur bacteria are released. The three studied fish species present omnivorous feeding habits. A. bahianus has a broad diet ingesting filamentous algae, macroalgae and detritus (Ferreira \& Goncalves 2006, Burkepile \& Hay 2008). A. saxatilis presents an opportunistic feeding behaviour with the ability to shift between food items according to season and environmental disturbances (Ferreira et al. 2004, Di Iulio Ilarri et al. 2008). Damselfish also present a high level of trophic plasticity, varying their diet composition according to their environment (Ceccarelli 2007, Frédérich et al. 2009, Feitosa et al. 2012). This study's results show that sulfur bacteria from the Bouillante geothermal plant are ingested by all these fish species and to our knowledge, such feeding behaviour has not been previously described. When this food resource is available, Acanthuridae such as A. bahianus and A. saxatilis are more abundant even while $S$. partitus abundance does not vary. It has been shown that abundances of species similar to Bouillante fish species (A. saxatilis) or genus (Stegastes fuscus and Acanthurus chirurgicus) are negatively affected by increased temperature (Teixeira et al. 2009, 2012). Consequently their occurrences around the Bouillante discharge channel are likely associated with their feeding behaviour. Abundances of Sergeant majors in Brazilian reefs similarly increased along with the availability of supplementary food (Di Iulio Ilarri et al. 2008). Damselfish are usually territorial species (Robertson 1996), additional food released by geothermal plant would consequently not increase size of territories and would not change damselfish abundances. After two weeks of absence of bacterial resource, A. bahianus and A. saxatilis presented a modified $\delta^{13} \mathrm{C}$, highlighting the role of bacteria in their diet. Isotopic turnover dynamics can vary according to species, tissue and the age of the taxon analysed (Bosley et al. 2002). Changes observed in the present study are consequently particularly 
rapid for adult fishes (Gajdzik et al. 2015). Our results show that the overall abundance of fish increased when sulfur bacterial food resource is available. This result is supported by several other studies, as in a shallow vent in Azores where fish, including species of the sergeantmajor genus Abudefduf, were found stationing themselves near the base of the plume, allowing them to benefit from food particle flows (Cardigos et al. 2005). Increased fish concentrations were also observed around a Californian oil seep (Spies \& Davis 1979) and a brine seep in the Gulf of Mexico (Bright et al. 1980). The irregular but predictable bacterial abundances in Bouillante allow us to determine that the fish aggregations are likely linked to the availability of sulfur bacteria as food.

Another organism was significantly affected by the presence of bacteria, namely, the sea urchin $D$. antillarum. This is a very common south Atlantic species which can occur in very high densities (Sammarco 1982). This species graze upon algae growing on rocks and is currently considered as a generalist herbivore ingesting micro- and macro-algae (Hawkins 1981). However D. antillarum can also be omnivorous (Karlson 1983, Rodríguez-Barreras et al. 2015) with the ability to selectively ingest food (Tuya et al. 2001). In Bouillante, D. antillarum is an opportunistic species with a diet composed mainly of sulfur bacteria when this resource is available. This data strengthens what is known about sea urchin trophic adaptation and also reveals that sulfur bacteria are a good food source for this species. In shallow hydrothermal vents, mats of sulfur oxidizing bacteria can be actively grazed by epistrate feeders such as abalone (Stein 1984), limpet (Trager \& De Niro 1990, Comeault et al. 2010) and nassariid (Southward et al. 1997). Similar ingestions of chemosynthetic bacterial filaments have been reported in a shallow cold seep for gastropods and the echinoid Pseudoechinus sp. (Zapata-Hernández et al. 2014b). At the hydrothermal vents of Kraternaya Bight, the sea urchin Strongylocentrotus droebachiensis is a dominant species in term of biomass and abundance (Tarasov 2006) and fatty acid reveals a considerable ingestion of 
sulfur bacteria by this urchin (Kharlamenko et al. 1995). As for fishes, this species was very abundant at our study sites and, therefore, its grazing activity may imply significant transfer of chemosynthetic production to a higher trophic level.

Nevertheless, most of the species sampled in this study did not used bacteria as a significant food source. The isotopic composition of the nematode community revealed a limited trophic role for bacteria coming from the geothermal source. Nematodes usually dominate meiofaunal communities in sediments around shallow hydrothermal vents, as in Italy (Colangelo et al. 2001), Greece (Thiermann et al. 1997), New Zealand (Kamenev et al. 1993), Papua New Guinea (Tarasov et al. 1999) and Indonesia (Zepilli \& Danovaro 2009). Dominance of nematodes over copepods is though to be due to their higher tolerance to chemical compounds released by vents (Jensen 1986). Depending on site conditions, abundances of nematodes around shallow vents can be reduced due to stressful chemical conditions (Thiermann et al. 1997, Tarasov et al. 1999, Colangelo et al. 2001) or increased when environmental conditions are less unfavourable (Kamenev et al. 1993, Tarasov 2006). Those increased abundances would be due to higher availability of food resources such as sulfur bacteria (Tarasov 2006). Despite environmental conditions suitable for meiofauna at the Bouillante discharge channel outlet, the diet composition of nematodes remains unchanged whether the chemosynthetic bacterial food is available or not.

The suspension-feeding mode dominates the studied epifauna. In order to extract a sufficient amount of food from a dilute environment, suspension-feeders present different mechanisms to screen, collect and transport particles (Riigsård \& Larsen 2010). Our sampling represented these different feeding modes. However, our results did not show any significant contribution of bacterial material to suspensivores, whatever their feeding modes. For instance, sponge filtering activity is based on pumping ambient water through aquiferous canals to choanocyte chambers where particles are retained (Riigsård \& Larsen 2010). This 
filtering system is specialized in retaining small prey, and bacteria are considered one of the primary sources of energy in sponge diets (Pile et al. 1996, Kowalke 2000). Symbiotic bacteria can also contribute to the nutrition of sponges and can represent $40 \%$ of their volume (Hentschel et al. 2006). A. fistularis is a bacteriosponge with nutrient resource dominated by DOM matter (Reiswig 1981). In the present study, this species is not affected by released water, suggesting that the geothermal plant is a limited influence on the total amount of DOM. I. birotulata is similarly uninfluenced even if this species is not considered as a bacteriosponge and should rely mostly on particulate organic carbon. Limited ingestion of sulfur bacteria by sponge species in comparison with other suspension-feeders has previously been observed in a shallow Mediterranean cave containing hot sulfur springs (Southward et al. 1996). It was also shown that the growth of sponges in Matupi Harbour is stimulated by hydrothermal fluid, meaning silicon concentration is increased aiding production of their skeleton, rather than by higher food resource availability with sulfur bacteria (Tarasov et al. 1999).

Barnacles rely principally on large prey such as zooplankton (Kuznetosa 1978, Richoux et al. 2014) or large macroalgae fragments (Dubois \& Colombo 2014) whereas the contribution of smaller prey like bacteria would be insignificant (Silina \& Zhukova 2016). Filaments of sulfur bacteria displaced from the discharge channel at Bouillante are large and visible with naked eye but are not assimilated by the barnacle Balanus sp. Using a fatty-acid profile approach, similar results were obtained with barnacles from a shallow hydrothermal vent in the Kurile Islands (Kharlamenko et al. 1995).

Bivalve species usually retain the majority of particles larger than $4 \mu \mathrm{m}$ (Riisgård et al. 2000). Qualitative factors of particles can influence their capture even if qualitative selection is assumed to be principally post-capture through a pre-ingestive selection using labial palps (Beninger et al. 1995, Riisgård et al. 2000). In the shallow vent of Kraternaya Bight, a bivalve 
species obtained most of its nutrition from endosymbiotic sulfur-oxidising bacteria whereas the bacterial input from food is limited for two other non symbiotic species (Kharlamenko et al. 1995). In California, the non symbiotic bivalve Mytilus edulis ingested only a small amount of sulfur-oxidising bacteria detached from mat of an intertidal vent (Trager \& De Niro 1990). Similarly, in the present study, sulfur-bacteria did not affect the diet composition of the non-symbiotic bivalve $S$. tenuis.

The gorgonian Pseudopterogorgia sp. is the only passive suspension-feeder examined in this study. Gorgonians can consume particulate organic matter ranging in size from nanometres to millimetres with a preference for nanoeukaryotic organisms such as ciliates and dinoflagellates (Ribes et al. 1998, 1999, Rossi et al. 2004). The present study suggests a limited trophic role for sulfur bacteria in gorgonians, but to our knowledge, such a role has never been documented. Similarly, the passive filter-feeder coral Porites californica was not affected by sulfur bacteria from a shallow vent in the Gulf of California (Forrest 2004).

Another trophic guild seemed unaffected by bacterial filament presence. The polychaete Hermodice carunculata is an important omnivorous scavenger in coral reef ecosystems (Jumars et al. 2015), feeding on various organisms including sea anemone, gorgonians, coral, benthic jellyfish (Barroso et al. 2015), starfish (Wolf et al. 2014) and dead fishes (Stoner \& Layman 2015). This opportunistic feeding behavior leads to highly variable isotopic composition in Bouillante fireworms, potentially preventing detection of any diet modification associated with sulfur bacteria. Nevertheless, shallow vent activity can be suitable for omnivorous scavengers such as gastropods (Southward et al. 1997) or crabs (Jeng et al. 2005, Wang et al. 2014) feeding on organisms killed by the chemical or thermal conditions of a vent plume. However, this trophic link seems to be limited in Bouillante where environmental conditions are less extreme and therefore less profitable for scavengers. 
Unlike in deep-sea environments, communities associated with shallow vents are not composed of vent-obligate species adapted to a chemosynthetic metabolism (Melwani \& Kim 2008). Shallow vent communities are often dominated by opportunistic species relatively scarce in the surrounding habitat (Southward et al. 1996, Karlen et al. 2010, Chan et al. 2016). Among some of the opportunistic species are polychaetes, gastropods and oligochaetes (Dando et al. 1995, Thiermann et al. 1997, Levin et al. 2003). In Bouillante, species benefiting from sulfur bacterial release are also opportunists regarding their feeding behaviour. All these species are mobile grazers or active pelagic feeders, whereas the suspension-feeders and predators were unaffected. Such restriction according to feeding mode was also observed in an intertidal hydrothermal vent, with ingestion of sulfur bacteria limited to grazers while suspension-feeders were similarly unaffected (Trager \& De Niro 1990).

In oligotrophic deep-sea environments most of the vent fauna rely on carbon fixed by chemosynthesis for nutrition (Van Dover 2000). At upper bathyal depths, inputs from photosynthetic organisms increase and dependence on chemosynthetic carbon would proportionally decrease (Levin \& Michener 2002, Levin 2005, Levin \& Mendoza 2007). In shallow vents the major food source is usually photosynthetic rather that chemosynthetic (Kharlamenko et al. 1995, Tarasov et al. 2005, Chan et al. 2016). However, despite this lower relative abundance of sulfur bacteria, they can still be used as food source in some shallow vent locations (Thiermann et al. 1997, Bosley et al. 2002, Forrest 2004, Comeault et al. 2010). The present study suggests that the emergence of chemosynthetic bacteria can influence food webs in coastal environments. The irregular flux of geothermal chemosynthetic bacteria reveals a trophic role restricted to mobile and opportunist species. 


\section{Figure and table}

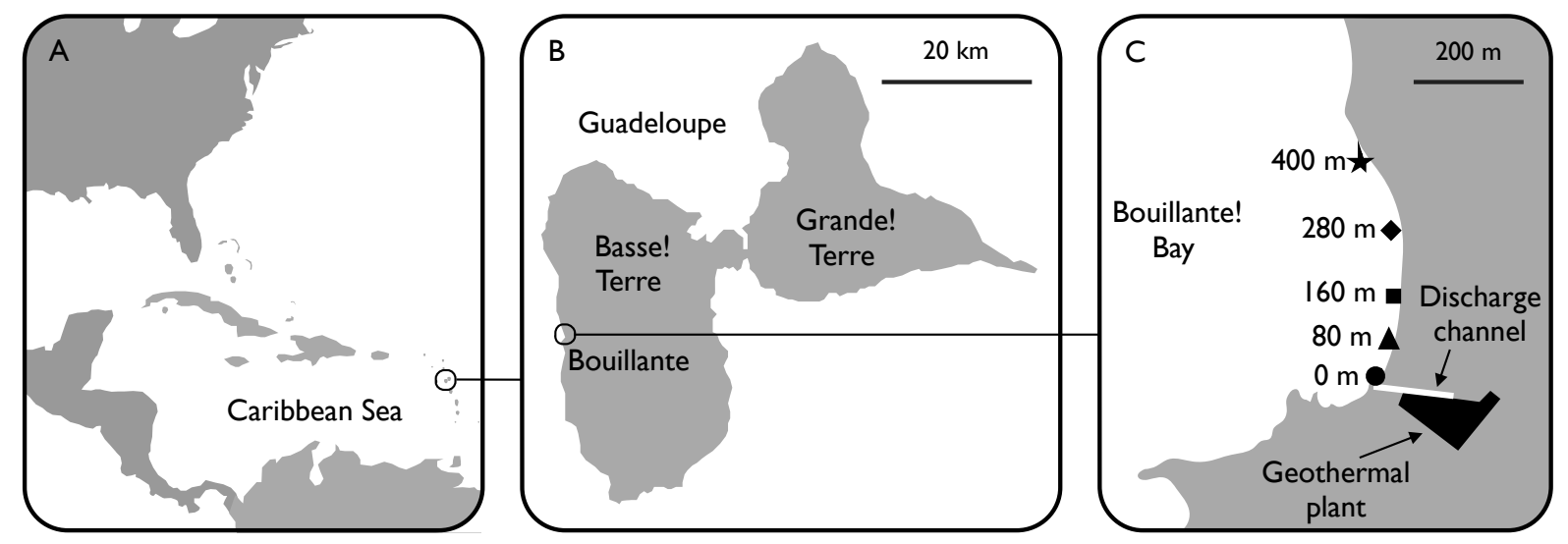

Figure 1. A: Location of Guadeloupe archipelago in the Caribbean Sea, B: Location of

Bouillante in Guadeloupe, C: Location of geothermal plant, discharge channel and five sampling stations in Bouillante Bay 


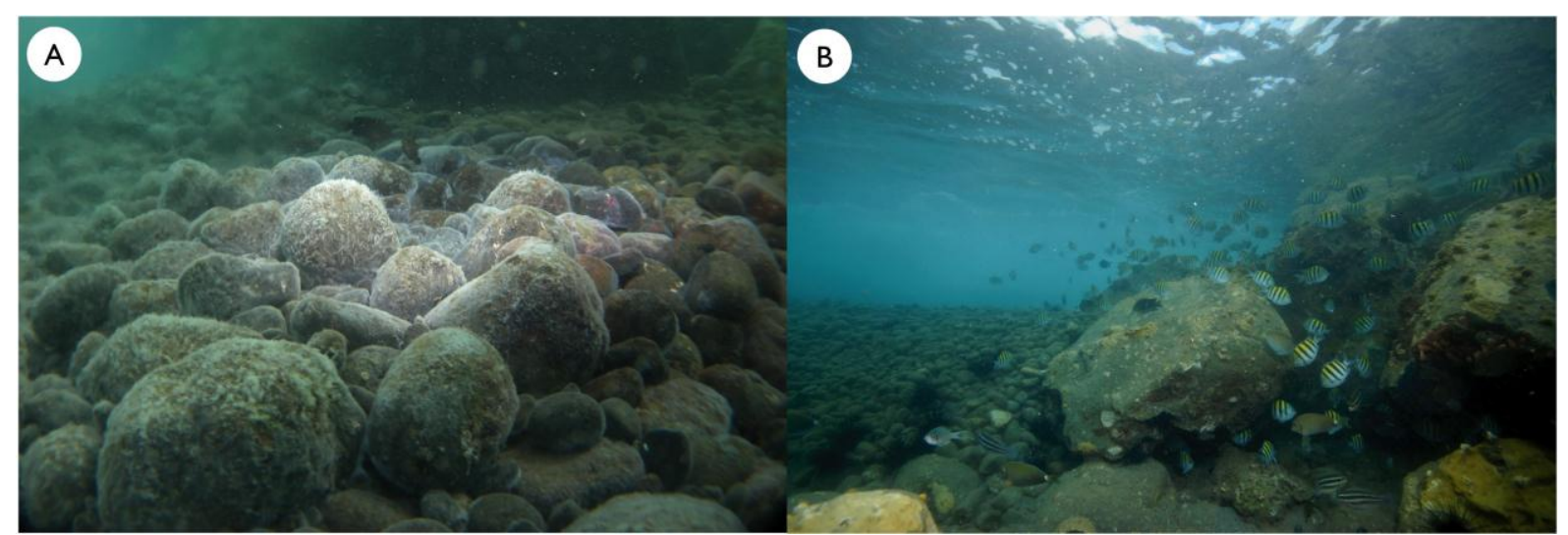

Figure 2. A: Thick biofilm of sulfur bacteria covering the bottom of the discharge channel, B:

Discharge channel outlet (in the left background of the picture) and aggregation of associated fishes (principally A. saxatilis and A. bahianus) 

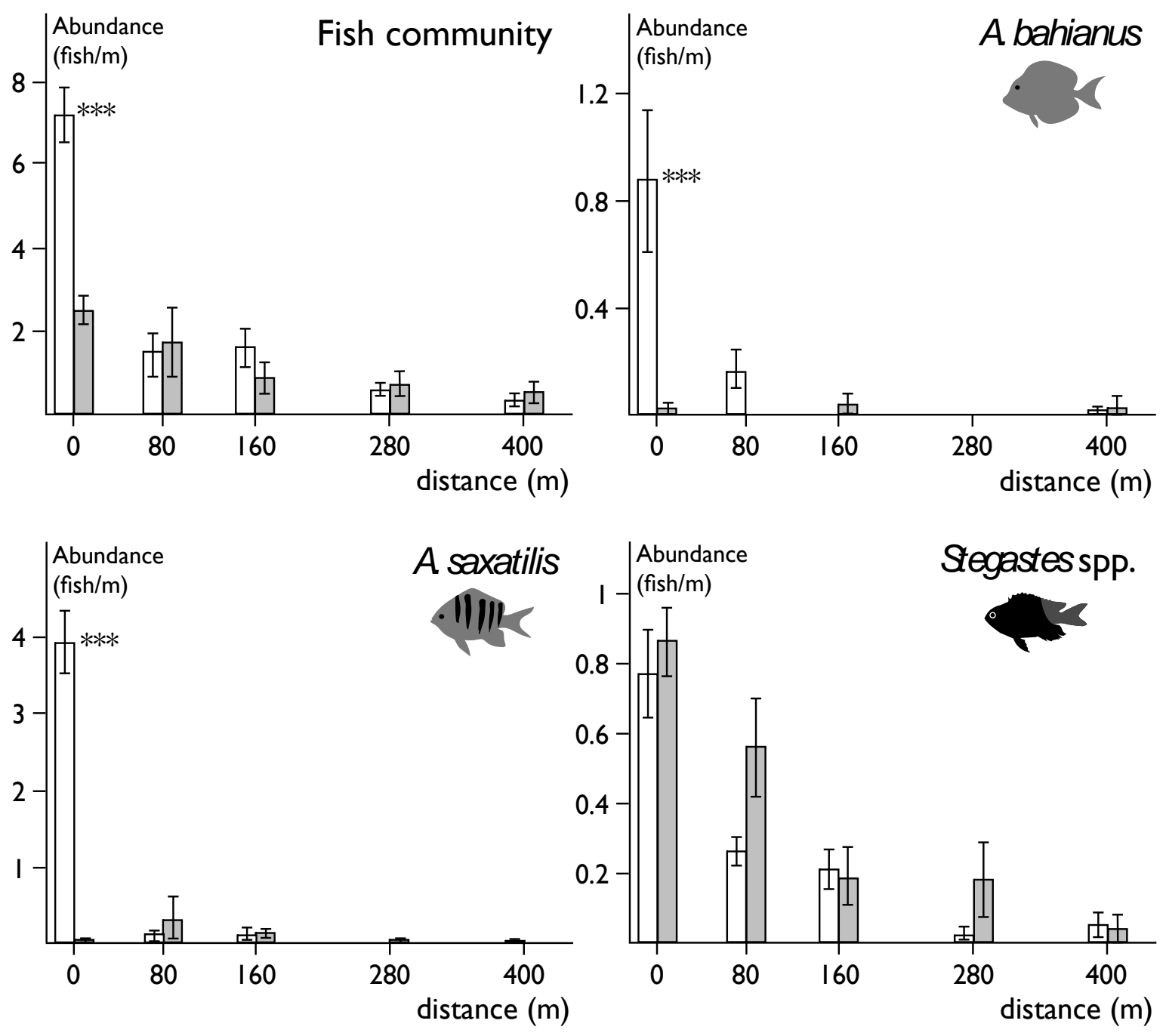

Figure 3. Abundance of fish community, A. bahianus, A. saxatilis and Stegastes spp. observed per meter of transect, per station, along the transect during regular (white) and stopped (grey) activity of the geothermal plant $(n=10)$. ***: Significant differences related to plant activity (bilateral t-test, $\mathrm{p}<0.001$ ) 


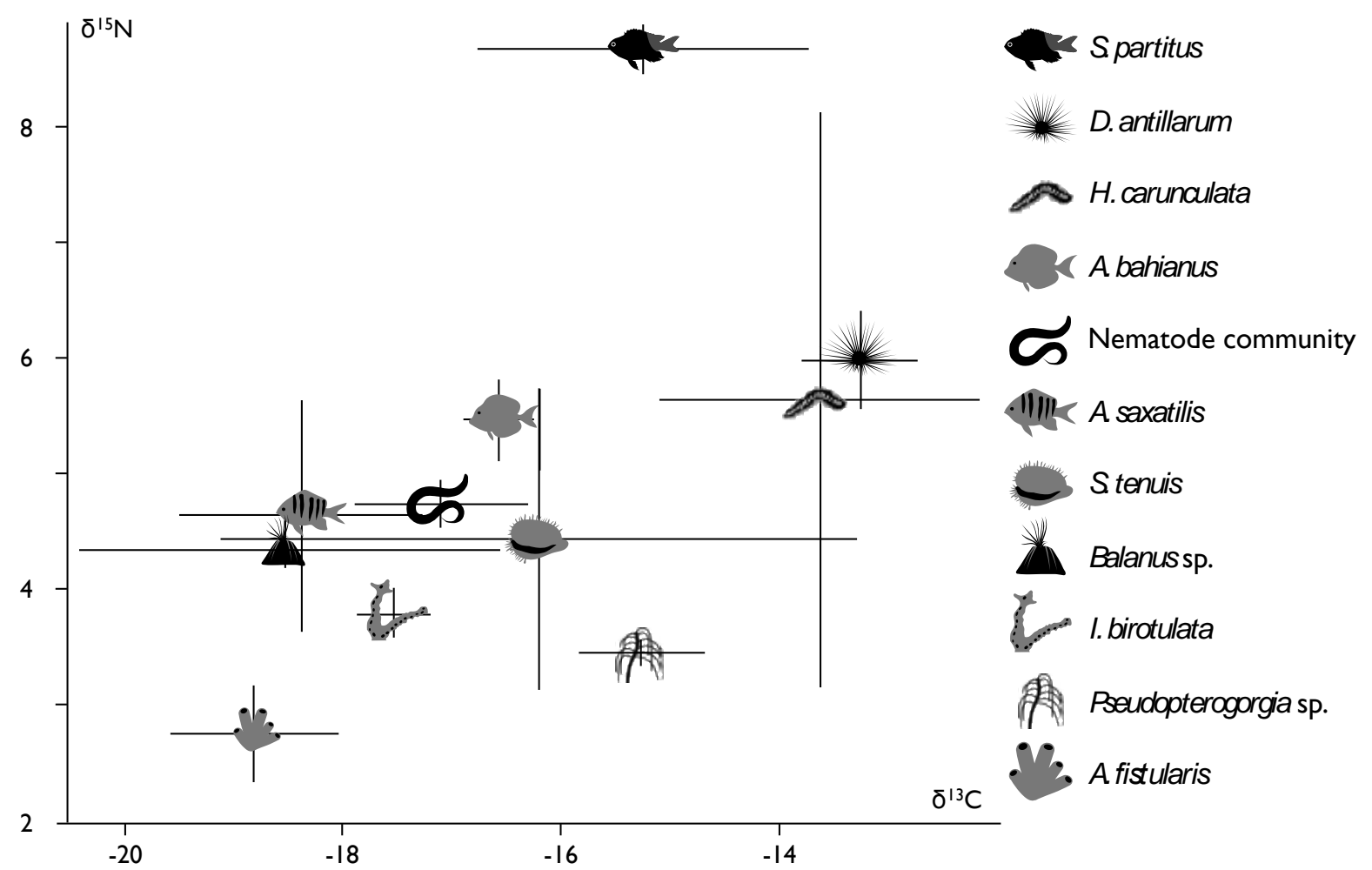

Figure 4. Isotopic composition $\left(\delta^{13} \mathrm{C}\right.$ and $\left.\delta^{15} \mathrm{~N}\right)$ of organisms at station $400 \mathrm{~m}( \pm \mathrm{SD} ; n=3)$. 


$$
\begin{aligned}
& \star \quad 400 \mathrm{~m} \\
& \text { - } 280 \mathrm{~m} \\
& \text { - } 160 \mathrm{~m} \\
& \text { - } 80 \mathrm{~m} \\
& \text { - } 0 \mathrm{~m}
\end{aligned}
$$
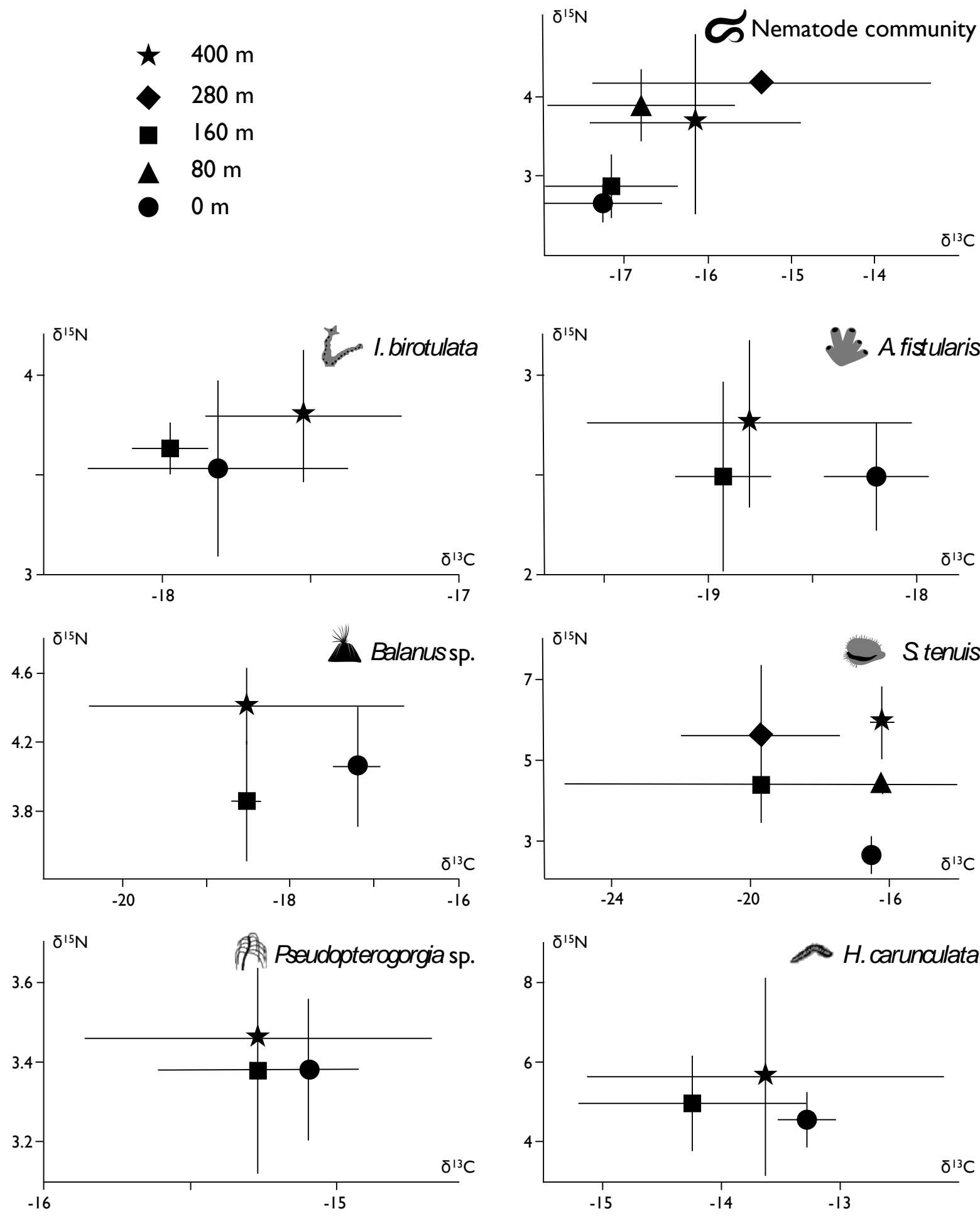
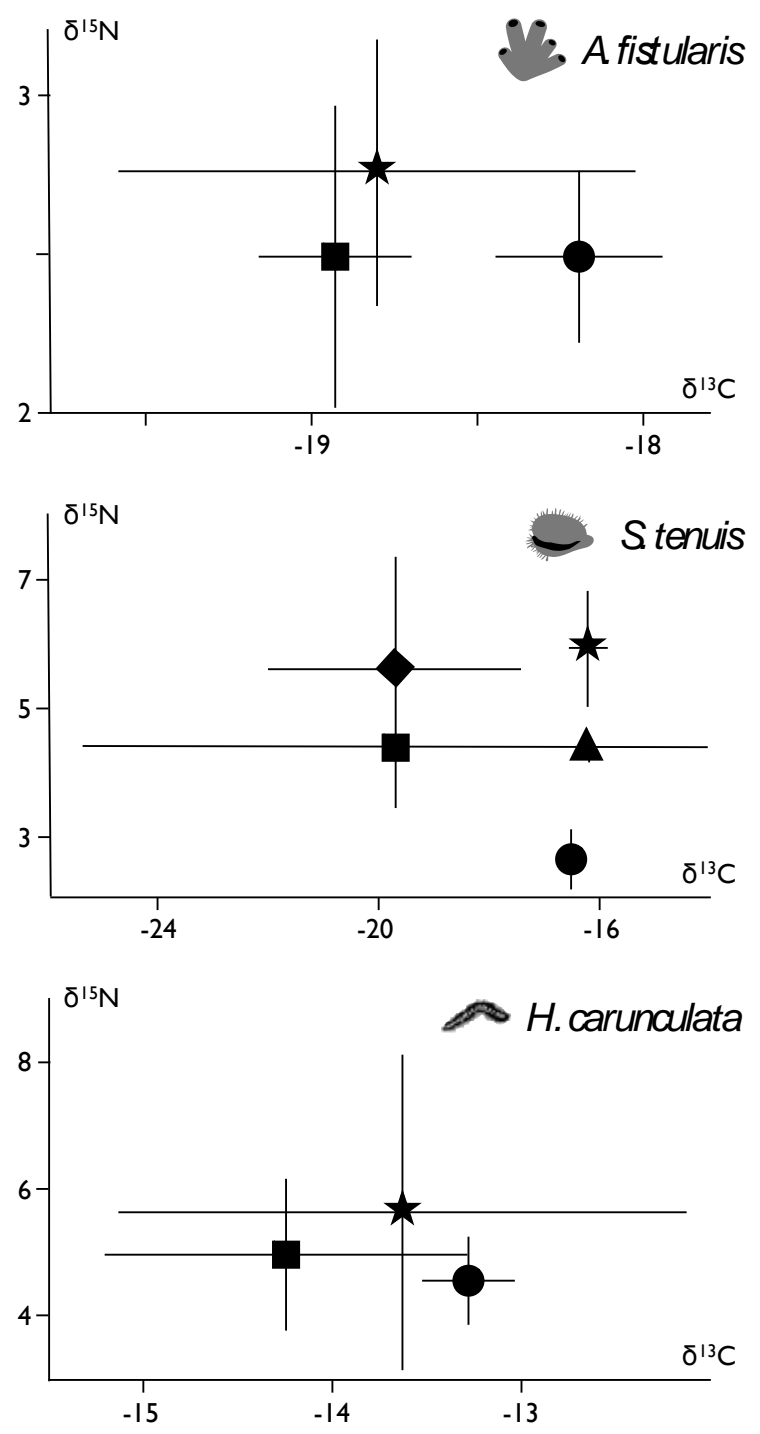

Figure 5. Isotopic compositions $\left(\delta^{13} \mathrm{C}\right.$ and $\left.\delta^{15} \mathrm{~N}\right)$ of nematode community, I. birotulata, $A$. fistularis, Balanus sp., S. tenuis, Pseudopterogorgia sp. and $H$. carunculata along transect stations $( \pm \mathrm{SD} ; n=3)$. Isotopic compositions are not significantly different according to station (Kruskall-Wallis tests, $\mathrm{p}>0.05$ ) 

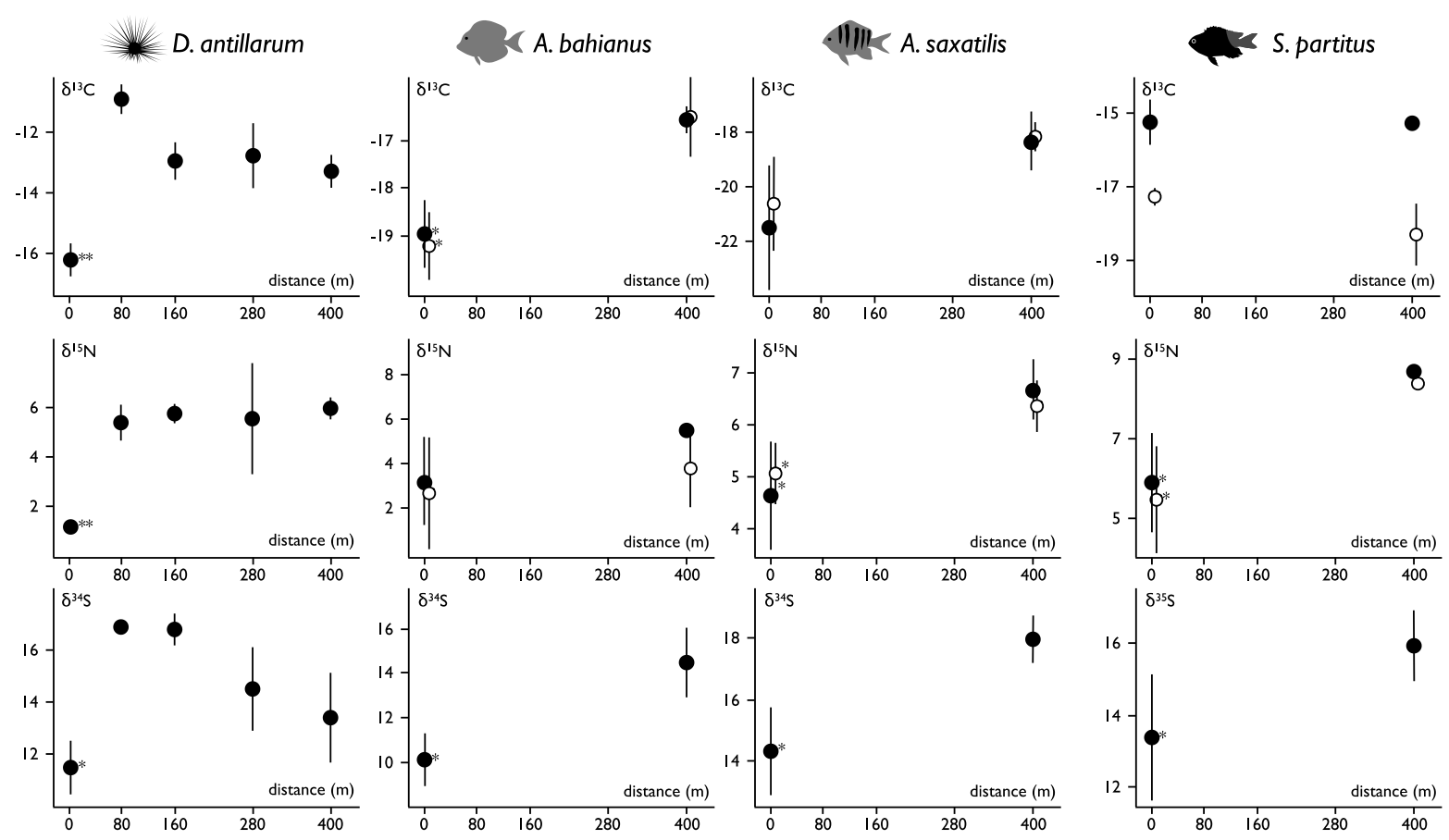

Figure 6. Isotopic compositions $\left(\delta^{13} \mathrm{C}, \delta^{15} \mathrm{~N}\right.$ and $\left.\delta^{34} \mathrm{~S}\right)$ of D. antillarum, A. bahianus, $A$. saxatilis and S. partitus of muscle (black dot) and stomach content (white dot) along transect stations $( \pm \mathrm{SD} ; n=3)$. *: Significant differences between station 0 and others (KruskallWallis tests, $* * \mathrm{p}<0.01, * \mathrm{p}<0.05)$ 

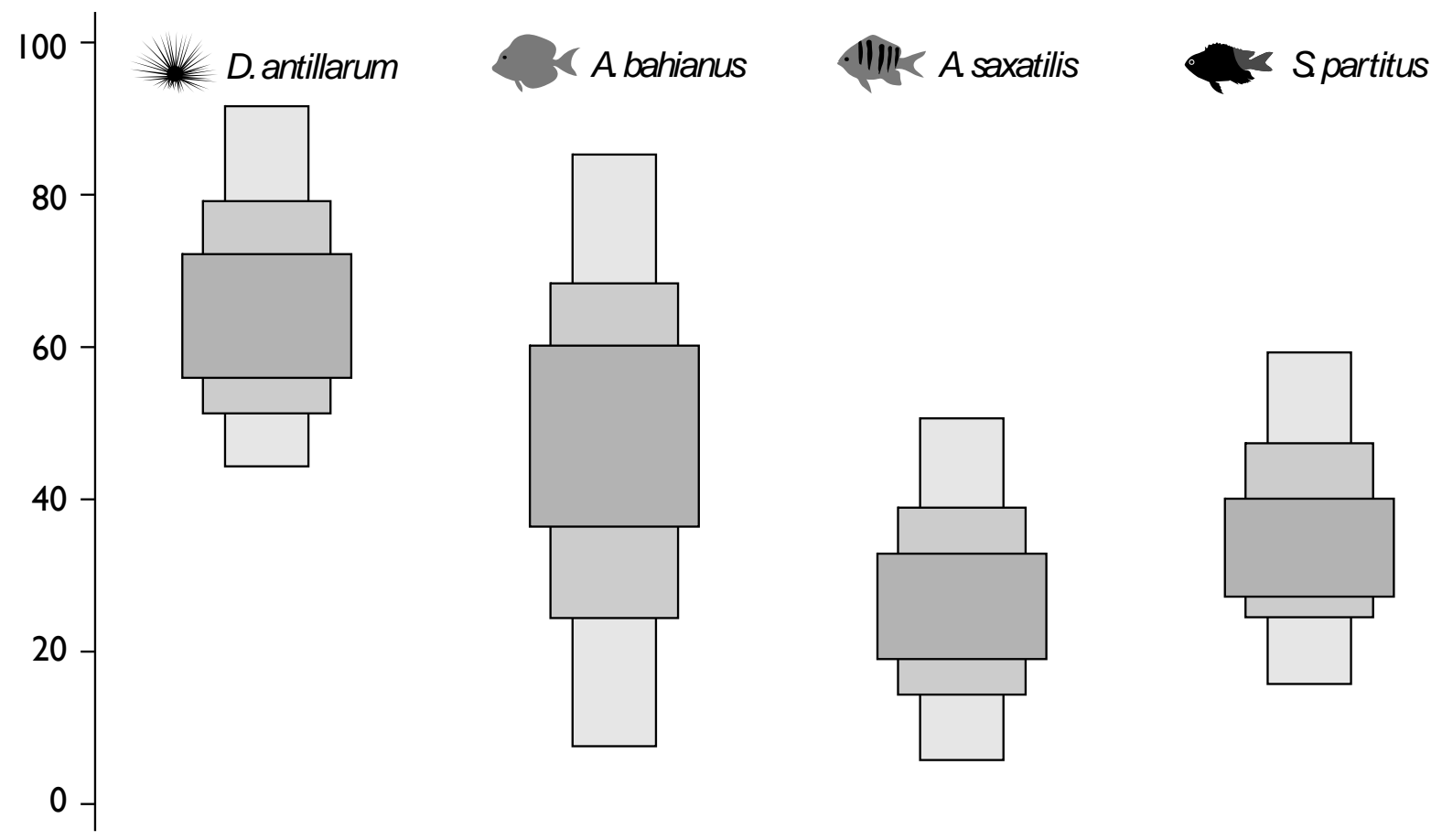

Figure 7. Contribution (\%) of bacteria to the diet of D. antillarum, A. bahianus, A. saxatilis and $S$. partitus at station $0 \mathrm{~m}$. Results were issued with the SIAR (Stable Isotope Analysis in R) mixing model with three isotopes (C, N and S) and two food sources (bacteria and average diet of each consumer evaluated at station $400 \mathrm{~m}$ ). 95,75 and $25 \%$ credibility intervals of probability distributions are reported. 

bacterial release

\begin{tabular}{lccc}
\hline A. bahianus & $\delta^{13} \mathrm{C}$ & $-18.94 \pm 0.74$ & $-16.60 \pm 0.95^{*}$ \\
& $\delta^{15} \mathrm{~N}$ & $3.21 \pm 1.99$ & $4.89 \pm 0.10$ \\
A. saxatilis & $\delta^{13} \mathrm{C}$ & $-21.49 \pm 2.31$ & $-16.95 \pm 0.61^{*}$ \\
& $\delta^{15} \mathrm{~N}$ & $4.64 \pm 1.02$ & $5.70 \pm 0.31$ \\
S. partitus & $\delta^{13} \mathrm{C}$ & $-15.24 \pm 0.62$ & $-14.19 \pm 0.79$ \\
& $\delta^{15} \mathrm{~N}$ & $5.88 \pm 1.00$ & $6.58 \pm 0.60$
\end{tabular}

Table 1. Isotopic compositions $\left(\delta^{13} \mathrm{C}\right.$ and $\left.\delta^{15} \mathrm{~N}\right)$ of muscles of three fish species (A. bahianus, A. saxatilis and $S$. partitus, $n=3$ ). during regular functioning of the geothermal plant and after two weeks' pause in functioning (*Kruskall-Wallis test, $\mathrm{p}<0.05)$ 


\section{$\underline{\text { Acknowledgements }}$}

We thank Sébastien Cordonnier (Université des Antilles) and David Fransolet for their assistance in the field, and Xavier Lourenço for his help in meiofaunal sorting. We thank Philippe Bouchet (Université Paris Sorbonne) for identification of Spondylus tenuis. We thank Olivier Hubert (CIRAD, Guadeloupe) and Maguy Dulorme (Université des Antilles) for their respective help with the freeze drier and ball mill. We thank Olivier Gros for comments on the manuscript. Gilles Lepoint is research Associate at Belgian National Fund for Scientific Research (F.R.S. FNRS). 
ANTEA (2005) Etude d'impact de l'unité Bouillante 2

Barroso R, Almeida D, Contins M, Filgueiras D, Dias R (2015) Hermodice carunculata (Pallas, 1766) (Polychaeta: Amphinomidae) preying on starfishes. Mar Biodiv

Beninger PG, Stjean SD, Poussard Y (1995) Labial palps of the blue mussel Mytilus edulis (Bivalvia, Mytilidae). Mar Biol 123:293-303

Bosley KL, Witting DA, Chambers RC, Wainright SC (2002) Estimating turnover rates of carbon and nitrogen in recently metamorphosed winter flounder Pseudopleuronectes americanus with stable isotopes. Mar Ecol Prog Ser 236:233-240

Bright TJ, Larock PA, Lauer RD, Brooks JM (1980) A brine seep at the East Flower Garden Bank, Northwestern Gulf of Mexico. Int Rev Gesamten Hydrobiol 65:535-549

Brombach T, Marini L, Hunziker JC (2000) Geochemistry of the thermal springs and fumaroles of Basse-Terre Island, Guadeloupe, Lesser Antilles. B Volcanol 61:477-490

Burkepile DE, Hay ME (2008) Herbivore species richness and feeding complementary affect community structure and function on a coral reef. P Natl Acad Sci USA 105:1620116206

Cardigos F, Colaço A, Dando PR, Ávila SP, Sarradin PM, Tempera PM, Conceição P, Pascoal A, Serrão Santos R (2005) Characterization of the shallow water hydrothermal vent field communities of the D. João de Castro Seamount (Azores). Chem Geol 224:153-168

Ceccarelli DM (2007) Modification of benthic communities by territorial damselfish: a multispecies comparison. Coral Reefs 26:853-866

Chan BKK, Wang TW, Chen PC, Lin CW, Chan TY, Tsang LM (2016) Community structure of macrobiota and environmental parameters in shallow water hydrothermal vents off Kueishan island, Taiwan. PLoS One:0148675

Colangelo MA, Bertasi R, Dall'Olio P, Ceccherelli VH (2001) Meiofaunal biodiversity on hydrothermal seepage off Panarea (Aeolian Island, Tyrrhenian Sea). In: Faranda FM, Guglielmo L, Spezie G (eds) Structure and processes in Mediterranean ecosystems. Springer-Verlag, Heidelberg

Comeault A, Stevens CJ, Juniper SK (2010) Mixed photosynthetic-chemosynthetic diets in vent obligate macroinvertebrate at shallow hydrothermal vents on Volcano 1, South Tonga Arc-Evidence from stable isotope and fatty acid analyses. Cah Biol Mar 51:351-359

Coplen TB (2011) Guidelines and recommended terms for expression of stable isotope ratio and gas-ratio measurement results. Rapid commun mass spectrom 25:2538-2560

Dando PR, Hughes JA, Leahy Y, Niven SJ, Taylor LJ, Smith C (1995) Gas venting rates from submarine hydrothermal areas around the island of Milos, Hellenic Volcanic Arc. Cont Shelf Res 15:913-929

de Jonge VN, Bouwman LA (1977) A simple density separation technique for quantitative isolation of meiobenthos using the colloidal silica Ludox-TM. Mar Biol 42:143-148

Di Iulio Ilarri M, De Souza AT, De Medeiros PR, Grempel RG, De Lucena Rosa IM (2008) Effects of tourist visitation and supplementary feeding on fish assemblage composition at Picãozinho reef, SW Atlantic. Neotrop ichthyol 6:651-656

Dubois SF, Colombo F (2014) How picky can you be? Temporal variations in trophic niches of co-occuring suspension-feeding species. Food Webs 1:1-9 
Feitosa JLL, Concentino AM, Teixeira SF, Ferreira BP (2012) Food resource use by two territorial damselfish (Pomacentridae: Stegastes) on South-Western Atlantic algaldominated reefs. J Sea Res 70:42-49

Ferreira CEL, Floeter SR, Gasparini JL, Ferreira BP, Joyeux JC (2004) Trophic structure patterns of Brazilian reef fishes: a latitudinal comparison. J Biogeogr 31:1093-1106

Ferreira CEL, Goncalves JEA (2006) Community structure and diet of roving herbivorous in the Abrolhos Archipelago, south-western Atlantic. J Fish Biol 69:1533-1551

Forrest MJ (2004) The geology, geochemistry and ecology of a shallow water submarine hydrothermal vent in Bahía Concepción, Baia California Sur, Mexico. University of Southern California

Frédérich B, Fabri G, Lepoint G, Vandewalle P, Parmentier E (2009) Trophic niches of thirteen damselfishes (Pomacentridae) at the Grand Récif of Toliara, Madagascar. Ichtyol Res 56:10-17

Gajdzik L, Lepoint G, Lecchini D, Frédérich B (2015) Comparison of isotopic turnover dynamics in two different muscles of a coral reef fish during the settlement phase. Sci Mar 79:325-333

Gamo T, Glasby CJ (2003) Submarine hydrothermal activity in coastal zones. In: Taniguchi M, Wang K, Gamo T (eds) Land and marine hydrogeology. Elsevier, Tokyo

Gattuso JP, Allemand D, Frankignoulle M (1999) Photosynthesis and calcification at cellular, organismal and community levels in coral reefs: a review on interactions and control by carbonate chemistry. Am Zool 39:160-183

Hawkins CM (1981) Efficiency of organic matter absorption by the tropical echinoid Diadema antillarum Philippi fed non-macrophytic algae. J Exp Mar Biol Ecol 49:244253

Hentschel U, Usher KM, Taylor MW (2006) Marine sponges as microbial fermenters. FEMS Microbiol Ecol 55:167-177

Jaud P, Lamethe D (1985) The Bouillante geothermal power-plant, Guadeloupe. Geothermics 14:197-205

Jeng MS, Ng NK, Ng PKL (2005) Feeding behaviour: Hydrothermal vent crabs feast on sea "snow". Nature 432:969

Jensen P (1986) Nematode fauna in the sulphide-rich brine seep and adjacent bottoms of the East Flower Garden, NW Gulf of Mexico. IV. Ecological Aspect. Mar Biol 92:489503

Jensen P, Aagaard I, Burke RA, Dando PR, Jørgensen NO, Kuijpers A, Laier T, O'Hara SCM, Schmaljohann R (1992) "Bubbling reefs" on the Kattegat: submarine landscapes of carbonate-cemented rocks support a diverse ecosystem at methane seeps. Mar Ecol Prog Ser 83:103-112

Judd AG, Sim R, Kingston P, McNally J (2002) Gas seepage on an intertidal site: Torry Bay, Firth of Forth, Scotland. Cont Shelf Res 22:2317-2331

Jumars PA, Kelly MD, Lindsay SM (2015) Diet of worms emended: an update of polychaete feeding guilds. Ann Rev Mar Sci 7:497-520

Kamenev GM, Fadeev VI, Selin NI, Tarasov VG, Malakhov VV (1993) Compositions and distribution of macro- and meiobenthos around sublittoral hydrothermal vents in the Bay of Plenty, New Zealand. N Z J Mar Freshwater Res 27:407-418

Karlen DJ, Price RE, Pichler T, Garey JR (2010) Changes in benthic macrofauna associated with a shallow-water hydrothermal vent gradient in Papua New Guinea. Pac Sci 64:391-404

Karlson RH (1983) Disturbance and monopolization of a spatial resource by Zoanthus sociatus (Coelenterata, Anthozoa). Bull Mar Sci 33:118-131 
Kennedy P, Kennedy H, Papadimitriou S (2005) The effect of acidification on the determination of organic carbon, total nitrogen and their stable isotopic composition in algae and marine sediment. Rapid commun mass spectrom 19:1063-1068

Kharlamenko VI, Zhukova NV, Khotimchenko SV, Svetashev VI, Kamenev GM (1995) Fatty acids as markers of food sources in a shallow-water hydrothermal ecosystem (Kraternaya Bight, Yankich Island, Kurile Islands). Mar Ecol Prog Ser 120:231-241

Kolasinki J, Rogers K, Frouin P (2008) Effects of acidification on carbon and nitrogen stable isotopes of benthic macrofauna from a tropical coral reef. Rapid commun mass spectrom 22:2955-2960

Kowalke J (2000) Ecology and energetics of two Antarctic sponges. J Exp Mar Biol Ecol 247:85-97

Kuznetosa IA (1978) Peculiarity of cirripedia nutrition. Hydrobiologicheskii Zhurnal 14:3741

Lachassagne P, Marechal JC, Sanjuan B (2009) Hydrogeological model of a high-energy geothermal field (Bouillante area, Guadeloupe, French West Indies). Hydrogeol J 17:1589-1606

Lefebvre S, Dubois SF (2017) The stony road to understand isotopic enrichment and turnover rates: insight into the metabolic part. Life Environ 66:305-314

Levin LA (2005) Ecology of cold deep sediments: interactions of fauna with flow, chemistry and microbes. Oceanogr Mar Biol 43:1-46

Levin LA, Mendoza GF (2007) Community structure and nutrition of deep methane-seep macrobenthos from the North Pacific (Aleutian) Margin and the Gulf of Mexico (Florida Escarpment). Mar Ecol 28:137-151

Levin LA, Michener RH (2002) Isotopic evidence for chemosynthesis-based nutrition of macrobenthos: the lightness of being at Pacific methane seeps. Limnol Oceanogr 47:1336-1345

Levin LA, Ziebis W, Mendoza GF, Growney VA, Mahn C, Gieskes JM, Tryon MD, Brown KM, Rathburn AE (2003) Spatial heterogeneity of macrofauna at northen California methane seeps: the influence of sulfide concentration and fluid flow. Mar Ecol Prog Ser 265:123-139

Mas A, Guisseau D, Patrier Mas P, Beaufort D, Genter A, Sanjuan B, Girard JP (2006) Clay minerals related to the hydrothermal activity of the Bouillante geothermal field (Guadeloupe). J Volcanol Geotherm Res 158:380-400

McCutchan JH, Lewis WM, Kendall C, McGrath CC (2003) Variation in trophic shift for stable isotope ratios of carbon, nitrogen, and sulfur. Oikos 102:378-390

Melwani AR, Kim SL (2008) Benthic infaunal distributions in shallow hydrothermal vent sediments. Acta Oecol 33:162-175

Montagna PA, Spies RB (1985) Meiofauna and chlorophyll associated with Beggiatoa mats of a natural submarine petroleum seep. Mar Environ Res 16:231-242

PARETO-IMPACTMER (2009) Rejets en mer de la centrale géothermique de Bouillante (Unité 1 et 2) : compléments à l'étude d'impacts de 2005, étude des biocénoses marines, CFG Service / Géothermie de Bouillante

Parnell AC, Inger R, Bearhop S, Jackson AL (2010) Source partitioning using stable isotopes: coping with too much variation. PLoS One 5:e9672

Pile AJ, Patterson MR, Witman JD (1996) In situ grazing on plankton $<10 \mu \mathrm{m}$ by the boreal sponge Mycale lingua. Mar Ecol Prog Ser 141:95-102

Powell EN, Bright TJ, Brooks JM (1986) The effect of sulfide and an increased food supply on the meiofauna and macrofauna at the East Flower Garden brine seep. Helgol Mar Res 40:57-82 
Reiswig HM (1981) Partial carbon and energy budgets of the bacteriosponge Verongia fistularis (Porifera, Demospongiae) in Barbados. Mar Ecol 2:273-293

Ribes M, Coma R, Gili JM (1998) Heterotrophic feeding by gorgonian corals with symbiotic zooxanthella. Limnol Oceanogr 43:1170-1179

Ribes M, Coma R, Gili JM (1999) Natural diet and grazing rate of the temperate sponge Dysidea avara (Desmospongiae, Dendroceratida) throughout an annual cycle. Mar Ecol Prog Ser 176:179-190

Richoux NB, Vermeulen I, Froneman PW (2014) Stable isotope ratios indicate differential omnivory among syntopic rocky shore suspension feeders. Mar Biol 161:971-984

Riigsård HU, Larsen PS (2010) Particle capture mechanisms in suspension-feeding invertebrates. Mar Ecol Prog Ser 418:255-293

Riisgård HU, Nielsen C, Larsen PS (2000) Dowstream collecting in ciliary suspension feeders: the catch-up principle. Mar Ecol Prog Ser 207:33-51

Robertson DR (1996) Interspecfic competition controls abundance and habitat use of territorial damselfishes. Ecology 77:885-899

Rodríguez-Barreras R, Cuevas E, Cabanillas-Terán N, Sabat AM (2015) Potential omnivory in the sea urchin Diadema antillarum? Reg Stud Mar Sci 2:11-18

Rossi S, Ribes M, Coma R, Gili J (2004) Temporal variability in zooplankton prey capture rate of the passive suspension feeder Leptogorgia sarmentosa (Cnidaria: Octocorallia), a case study. Mar Biol 144:89-99

Sammarco PW (1982) Echnioid grazing as a structuring force in coral communities: whole reef manipulations. J Exp Mar Biol Ecol 61:31-55

Sanjuan B, Lasne E, Brach M (2001) Bouillante geothermal fluid: mixing and water/rock interaction processes at $250^{\circ} \mathrm{C} 10$ th Water-Rock interaction, Cagliari, $\mathrm{p}$ 911-914

Sellanes J, Zapata-Hernández G, Pantoja S, Jessen GL (2011) Chemosynthetic trophic support for the benthic community at an intertidal seep site at Mocha Island off central Chile. Estuar Coast Shelf Sci 95:431-439

Silina AV, Zhukova NV (2016) Association of the scallop Patinopecten yessoensis and epibiotic barnacle Balanus rostratus: inter-specific interactions and trophic relationships. Mar Ecol 37:257-268

Southward AJ, Kennicutt MC, Alcala-Herrera J, Abbiati M, Airoldi L, Cinelli F, Bianchi CN, Morri C, Southward EC (1996) On the biology of submarine caves with sulphur springs: ${ }^{13} \mathrm{C} /{ }^{12} \mathrm{C}$ ratios as a guide to trophic relations. J Mar Biol Assoc U K 76:265285

Southward AJ, Southward EC, Dando PR, Hughes JA, Kennicutt II MC, Alcala-Herrera J, Leahy Y (1997) Behaviour and feeding of the nassariid gastropod Cyclope neritea, abundant at hydrothermal brine seeps off Milos (Aegean sea). J Mar Biol Assoc U K 77:753-771

Spies RB, Davis PH (1979) The infaunal benthos of a natural oil seep in the Santa Barbara Channel. Mar Biol 50:227-237

Spies RB, DesMarais DJ (1983) Natural isotope study of trophic enrichment of marine benthic communities by petroleum seepage Mar Biol 73:67-71

Stein JL (1984) Subtidal gastropods consume sulfur oxidizing bacteria: evidence from coastal hydrothermal vents. Science 223:696-698

Stoner EW, Layman CA (2015) Bristle worms attack: benthic jellyfish are not trophic dead ends. Front Ecol Environ 13:226-227

Sweetman AK, Levin LA, Rapp HT, Schander C (2013) Faunal trophic structure at hydrothermal vents on the southern Mohn's Ridge, Artic Ocean. Mar Ecol Prog Ser 473:115-131 
Tarasov VG (2006) Effects of shallow-water hydrothermal venting on biological communities of coastal marine ecosystems of the western Pacific. Adv Mar Biol 50:267-421

Tarasov VG, Gebruk AV, Mironov AN, Moskalev LI (2005) Deep-sea and shallow-water hydrothermal vent communities: two different phenomena? Chem Geol 224:5-39

Tarasov VG, Gebruk AV, Shulkin VM, Kamenev GM, Fadeev VI, Kosmynin VN, Malakhov VV, Starynin DA, Obzhirov AI (1999) Effect of shallow-water hydrothermal venting on the biota of Matupi Harbour (Rabaul Caldera, New Britain Island, Papua New Guinea). Cont Shelf Res 19:79-116

Teixeira TP, Neves LM, Araújo FG (2009) Effects of a nuclear power plant thermal discharge on habitat complexity and fish community structure in Iha Grande Bay, Brazil. Mar Environ Res 68:188-195

Teixeira TP, Neves LM, Araújo FG (2012) Thermal impact of a nuclear power plant in a coastal area in Southeastern Brazil: effects of heating and physical structure on benthic cover and fish communities. Hydrobiologia 684:161-175

Thiermann F, Akoumianaki I, Hughes JA, Giere O (1997) Benthic fauna of a shallow-water gaseohydrothermal vent area in the Aegean Sea (Greece). Mar Biol 128:149-159

Trager GC, De Niro MJ (1990) Chemoautotrophic sulphur bacteria as food source for mollusks at intertidal hydrothermal vents: evidence from stable isotopes. Veliger 33:359-362

Tunnicliffe V (1991) The biology of hydrothermal vents: ecology and evolution. Oceanogr Mar Biol 29:319-407

Tuya F, Martín JA, Reuss GM, Luque A (2001) Food preference of the sea urchin Diadema antillarum in Gran Canaria (Canary Islands, central-east Atlantic Ocean). J Mar Biol Assoc U K 81:845-849

Van Dover CL (2000) The ecology of Deep-Sea Hydrothermal Vents, Vol. Princeton University Press, Princeton

Vander Zanden MJ, Clayton MK, Moody EK, Solomon CT, Weidel BC (2015) Stable isotope turnover and half-life in animal tissues: a literature synthesis. PloS One 10:e0116182

Wang TW, Chan TY, Chan BBK (2014) Trophic relationships of hydrothermal vent and nonvent communities in the upper sublittoral and upper bathial zones off Kueishan Island, Taiwan: a combined morphological, gut content analysis and stable isotope approach. Mar Biol 161:2447-2463

Wolf AT, Nugues MM, Wild C (2014) Distribution, food preference, and trophic position of the corallivorous fireworm Hermodice carunculata in a Caribbean coral reef. Coral Reefs 33:1153-1163

Zapata-Hernández G, Sellanes J, Mayr C, Muñoz P (2014a) Benthic food web structure in the Comau fjord, Chile $\left(\sim 42^{\circ} \mathrm{S}\right)$ : Preliminary assessment including a site with chemosynthetic activity. Prog Oceanogr 129:149-158

Zapata-Hernández G, Sellanes J, Thurber AR, Levin LA, Chazalon F, Linke P (2014b) New insights on the trophic ecology of bathyal communities from the methane seep area off Concepción, Chile ( $\left.42^{\circ} \mathrm{S}\right)$. Mar Ecol 35:1-21

Zepilli D, Danovaro R (2009) Meiofaunal diversity and assemblages structure in a shallowwater hydrothermal vent in the Pacific Ocean. Aquat Biol 5:75-84 